Cytologia focus:

\title{
FISH Is in the Limelight Again As More Than a Cytogenetical Technique for Metaphase Chromosomes
}

\author{
Sachihiro Matsunaga* \\ Department of Applied Biological Science, Faculty of Science and Technology, Tokyo University of Science, \\ 2641 Yamazaki, Noda, Chiba 278-8510, Japan \\ Received February 9, 2016; accepted February 12, 2016
}

\begin{abstract}
Summary Fluorescent in situ hybridization (FISH) has been a powerful technique to reveal chromosomal loci and distribution of DNA sequences in metaphase chromosomes. Three-dimensional FISH (3D-FISH) has also revealed the chromosome territory of interphase chromosomes in the nucleus. Recently, 3D-FISH has played a supportive or complementary role to confirm the genome organization and topologically associated domains, which are provided by chromosome conformation capture techniques.
\end{abstract}

Key words FISH, Banding, Hi-C, Chromosome, Topologically associated domain, Chromosome conformation capture, Chromosome territory, Genome organization.

Cytogenetical techniques for mitotic chromosomes have revealed karyotypes and chromosomal arrangements (Maneechot et al. 2015, Phimphan et al. 2015). Chromosome banding techniques contribute not only to karyotyping but also to the identification of specific chromosomes (Afroz et al. 2013, Alam et al. 2013a, 2013b, Sultana et al. 2013, Lombello and Pinto-Maglio 2014, Mahbub et al. 2014, Manzum et al. 2014, Tungkajiwangkoon et al. 2015). Some chromosome banding techniques, including C-banding and G-banding, are strongly dependent on heterochromatin distribution in mitotic chromosomes (Sumner 2003, Bansal and Kaur 2015). Recent chromosome banding with fluorescent stains can represent the difference of GC content along mitotic chromosomes. Chromosome banding with chromomycin $\mathrm{A}_{3}$ can reveal GC-rich regions, whereas that with 4',6-diamidino-2-phenylindole can highlight ATrich regions (Akter et al. 2015, Hizume 2015, Hizume and Kan 2015, Imran et al. 2015).

Fluorescent in situ hybridization (FISH) can identify mitotic chromosomes and reveal specific genomic loci or distribution of DNA sequences in more detail (Hizume et al. 2013, Ikeda et al. 2013, Kuroki et al. 2013, Ruan et al. 2013, Yokomi et al. 2013, Kantek et al. 2015). FISH procedures include the preparation of metaphase chromosomes, labeling of probes, DNA denaturation, hybridization, detection of probes with fluorescent antibodies and observation by fluorescent microscopy (Shibata and Hizume 2015). Moreover, multiplex FISH with the mixture of each genome from a single pair of

*Corresponding author, e-mail: sachi@rs.tus.ac.jp DOI: $10.1508 /$ cytologia.81.3 homologous chromosomes as multicolor probes, which is also called chromosome painting, can identify each chromosome and elucidate chromosome synteny and translocation (Suto et al. 2003, 2012, 2013).

FISH has also been challenged to answer the question of how decondensed chromosomes are arranged in the nucleus. Interphase chromosomes are spatially compressed into subnuclear regions with territorial organization (Rabl 1885, Boveri 1909, Cremer et al. 1982). This spatial occupation of interphase chromosomes is called chromosome territory (Cremer et al. 1996, Cremer and Cremer 2010; Fig. 1). Three-dimensional FISH (3DFISH) is performed by confocal microscopy. 3D-FISH visualized the location of interphase chromosomes in nuclei and revealed conserved rules of chromosome territory and chromosome positioning (Dernburg et al. 1996, Solovei et al. 2002).

In the last decade, several chromosome conformation capture techniques, which can quantify chromatin contacts, have disclosed the folded state of genomes in interphase nuclei (Dekker et al. 2013, Fraser et al. 2015). In particular, a chromosome conformation capture technique in combination with deep sequencing, $\mathrm{Hi}-\mathrm{C}$, can reveal the spatial genome organization in the whole genome through the frequency of the DNA interaction with each other. This genome organization has been confirmed by 3D-FISH (Markenscoff-Papadimitriou et al. 2014, Feng et al. 2014, Grob et al. 2014). Chromosome conformation capture techniques also proposed a chromosomal module at sub-Mb scale, which is termed a topologically associated domain (TAD) (Fig. 1; Nora et al. 2013). TADs are more discrete chromatin structures consisting of chromosome territory (Gibcus and Dekker 


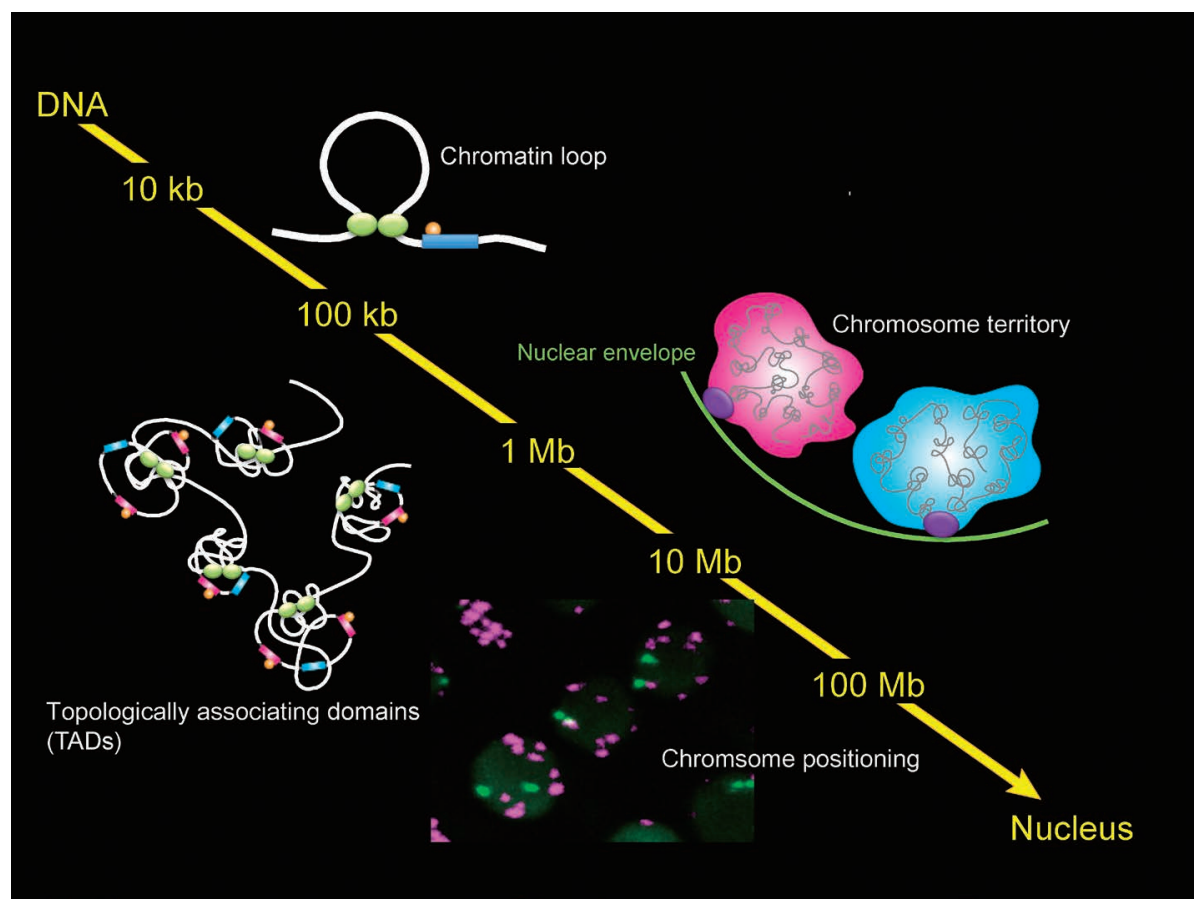

Fig. 1. Hierarchy of three-dimensional structures of chromatin in the nucleus.

2013). The distribution of TADs is also supported by 3D-FISH (Nora et al. 2012). However, some genome organization revealed by chromosome conformation capture techniques could not be confirmed by 3D-FISH (Williamson et al. 2014). The inconsistency would be derived from the technical difference between FISH and Hi-C. FISH is a hybridization-based technique strongly dependent on the length of probes and the compaction state of the targeted chromatin. Although Hi-C can reveal DNA sequence-based data with high resolution, it tends to offer more intrachromosomal contacts than interactions between different chromosomal DNAs (Lieberman-Aiden et al. 2009). Beyond the technical difference, the inconsistency may be explained by the ploidy state including endoreduplication (Matsunaga and Umeda 2011, Matsunaga et al. 2013, Hayashi et al. 2013) and aneuploidy (Gordon et al. 2012). In addition, FISH discloses genome organization at a single nuclear level, whereas most $\mathrm{Hi}-\mathrm{C}$ data were provided using a vast number of nuclei isolated from cell populations. However, Hi-C using a single cell (Nagano et al. 2013, 2015, Kind et al. 2015) or in combination with a 3DFISH-calibration software (Shavit et al. 2014) will fill the gap between 3D-FISH and conventional Hi-C data.

\section{Acknowledgements}

This work was supported by CREST grants from the Japan Science and Technology Agency to S. M. and MEXT/JSPS KAKENHI to S. M. I thank Mr. Takeshi Hirakawa for his generous support to prepare Fig. 1.
References

Afroz, M., Sultana, S. S. and Alam, S. S. 2013. Karyotype and RAPD analysis of three morphological forms of Alocasia fornicata (Roxb.) Schott. Cytologia 78: 269-275.

Akter, L., Mahbub, M., Habib, M. A. and Alam, S. S. 2015. Characterization of three varieties of Lathyrus sativus $\mathrm{L}$. by fluorescent karyotype and RAPD analysis. Cytologia 80: 457-465.

Alam, S. S., Nahar, L., Habib, Md. A. and Sultana, S. S. 2013a. Cytogenetical and molecular characterization of $S$. violaceum, $S$. sisymbrifolium and a putative hybrid between 우 $S$. violaceum and $\sigma^{7}$ S. melongena. Cytologia 78: 35-41.

Alam, S. S., Tasmin, R., Jahan, I., Habib, Md. A. and Sultana, S. S. 2013b. Fluorescent banding and RAPD analysis of five cultivars in Vigna unguiculata ssp. sesquipedalis (L.) Verdc. Cytologia 78: $73-79$.

Bansal, N. and Kaur, H. 2015. C-Heterochromatin distribution and its base composition in four species of Mictini (Heteroptera, Coreidae, Coreinae). Cytologia 80: 405-413.

Boveri, T. 1909. Die Blastomerenkerne von Ascaris megalocephala und die Theorie der Chromosomenindividualität. Wilhelm Engelmann, Leipzig.

Cremer, C., Münkel, C., Granzow, M., Jauch, A., Dietzel, S., Eils, R., Guan, X. Y., Meltzer, P. S., Trent, J. M., Langowski, J. and Cremer, T. 1996. Nuclear architecture and the induction of chromosomal aberrations. Mutat. Res. 366: 97-116.

Cremer, T., Cremer, C., Baumann, H., Luedtke, E. K., Sperling, K., Teuber, V. and Zorn, C. 1982. Rabl's model of the interphase chromosome arrangement tested in Chinese hamster cells by premature chromosome condensation and laser-UV-microbeam experiments. Hum. Genet. 60: 46-56.

Cremer, T. and Cremer, M. 2010. Chromosome territories. Cold Spring Harb. Perspect. Biol. 2: a003889.

Dekker, J., Marti-Renom, M. A. and Mirny, L. A. 2013. Exploring the three-dimensional organization of genomes: interpreting chromatin interaction data. Nat. Rev. Genet. 14: 390-403.

Dernburg, A. F., Broman, K. W., Fung, J. C., Marshall, W. F., Philips, J., Agard, D. A. and Sedat, J. W. 1996. Perturbation of nuclear 
architecture by long-distance chromosome interactions. Cell 85: 745-759.

Feng, S., Cokus, S. J., Schubert, V., Zhai, J., Pellegrini, M. and Jacobsen, S. E. 2014. Genome-wide Hi-C analyses in wild-type and mutants reveal high-resolution chromatin interactions in Arabidopsis. Mol. Cell 55: 694-707.

Fraser, J., Williamson, I., Bickmore, W. A. and Dostie, J. 2015. An overview of genome organization and how we got there: From FISH to Hi-C. Microbiol. Mol. Biol. Rev. 79: 347-372.

Gibcus, J. H. and Dekker, J. 2013. The hierarchy of the 3D genome. Mol. Cell 49: 773-782

Gordon, D. J., Resio, B. and Pellman, D. 2012. Causes and consequences of aneuploidy in cancer. Nat. Rev. Genet. 13: 189-203.

Grob, S., Schmid, M. W. and Grossniklaus, U. 2014. Hi-C analysis in Arabidopsis identifies the KNOT, a structure with similarities to the flamenco locus of Drosophila. Mol. Cell 55: 678-693.

Hayashi, K., Hasegawa, J. and Matsunaga, S. 2013. The boundary of the meristematic and elongation zones in roots: Endoreduplication precedes rapid cell expansion. Sci. Rep. 3: 2723.

Hizume, M. 2015. Fluorescent band pattern of chromosomes in Pseudolarix amabilis, Pinaceae. Cytologia 80: 151-157.

Hizume, M. and Kan, M. 2015. Fluorescent banding pattern of chromosomes in Araucaria araucana, Araucariaceae. Cytologia 80: 399-403.

Hizume, M., Shiraishi, H., Matsusaki, Y. and Shibata, F. 2013. Localization of $45 \mathrm{~S}$ and $5 \mathrm{~S}$ rDNA on chromosomes of Nigella damascena, Ranunculaceae. Cytologia 78: 379-381.

Ikeda, K., Sato, S., Matoba, H., Nagano, K. and Uchiyama, H. 2013. Molecular cytogenetic analysis of the critically endangered Trigonotis radicans var. radicans and var. sericea and allied species in Japan. Cytologia 78: 297-303.

Imran, M. K., Sultana, S. S. and Alam, S. S. 2015. Differential chromosome banding and RAPD analysis in three varieties of Glycine $\max ($ L.) Merr. Cytologia 80: 447-455.

Kantek, D. L. Z., Peres, W. A. M. and Moreira-Filho, O. 2015. Cytogenetics of Trichomycterus brasiliensis (Siluriformes: Trichomycteridae) from the upper São Francisco River basin (MG). Cytologia 80: 25-29.

Kind, J., Pagie, L., de Vries, S. S., Nahidiazar, L., Dey, S. S., Bienko, M., Zhan, Y., Lajoie, B., de Graaf, C. A., Amendola, M., Fudenberg, G., Imakaev, M., Mirny, L. A., Jalink, K., Dekker, J., van Oudenaarden, A. and van Steensel, B. 2015. Genome-wide maps of nuclear lamina interactions in single human cells. Cell 163: 134-147.

Kuroki, Y., Shibata, F. and Hizume, M. 2013. Chromosome bandings and signal pattern of FISH using rDNAs in Bellevalia romana. Cytologia 78: 399-401.

Lieberman-Aiden, E., van Berkum, N. L., Williams, L., Imakaev, M., Ragoczy, T., Telling, A., Amit, I., Lajoie, B. R., Sabo, P. J., Dorschner, M. O., Sandstrom, R., Bernstein, B., Bender, M. A., Groudine, M., Gnirke, A., Stamatoyannopoulos, J., Mirny, L. A., Lander, E. S. and Dekker, J. 2009. Comprehensive mapping of long-range interactions reveals folding principles of the human genome. Science 326: 289-293.

Lombello, R. A. and Pinto-Maglio, C. A. F. 2014. Cytogenetics and reproductive biology of Bixa orellana L. (Bixaceae). Cytologia 79: $379-386$

Mahbub, M., Sultana, S. S., Habib, Md. A. and Alam, S. S. 2014. Karyotype and RAPD analysis of Allium tuberosum Rottl. ex Spreng. and three specimens of Allium cepa L. Cytologia 79: 409-418.

Maneechot, N., Supiwong, W., Jumrusthanasan, S., Siripiyasing, P., Pinthong, K. and Tanomtong, A. 2015. Chromosomal characteristics of the Royal Knifefish, Chitala blanci (Osteoglossiformes, Notopteridae) by conventional and Ag-NOR staining techniques. Cytologia 80: 159-166.
Manzum, A. A., Sultana, S. S., Warasy, A. A., Begum, R. and Alam, S. S. 2014. Characterization of four specimens of Allium sativum L. by differential karyotype and RAPD analysis. Cytologia 79: 419-426.

Markenscoff-Papadimitriou, E., Allen, W. E., Colquitt, B. M., Goh, T., Murphy, K. K., Monahan, K., Mosley, C. P., Ahituv, N. and Lomvardas, S. 2014. Enhancer interaction networks as a means for singular olfactory receptor expression. Cell 159: 543-557.

Matsunaga, S. and Umeda, M. 2011. DNA double-strand breaks induce endoreduplication. Cytologia 76: 229-230.

Matsunaga, S., Katagiri, Y., Nagashima, Y., Sugiyama, T., Hasegawa, J., Hayashi, K. and Sakamoto, T. 2013. New insights into the dynamics of plant cell nuclei and chromosomes. Int. Rev. Cell Mol. Biol. 305: 253-301.

Nagano, T., Lubling, Y., Stevens, T. J., Schoenfelder, S., Yaffe, E., Dean, W., Laue, E. D., Tanay, A. and Fraser, P. 2013. Single-cell $\mathrm{Hi}-\mathrm{C}$ reveals cell-to-cell variability in chromosome structure. Nature 502: 59-64.

Nagano, T., Lubling, Y., Yaffe, E., Wingett, S. W., Dean, W., Tanay, A. and Fraser, P. 2015. Single-cell Hi-C for genome-wide detection of chromatin interactions that occur simultaneously in a single cell. Nat. Protoc. 10: 1986-2003.

Nora, E. P., Dekker, J. and Heard, E. 2013. Segmental folding of chromosomes: A basis for structural and regulatory chromosomal neighborhoods? BioEssays 35: 818-828.

Nora, E. P., Lajoie, B. R., Schulz, E. G., Giorgetti, L., Okamoto, I., Servant, N., Piolot, T., van Berkum, N. L., Meisig, J., Sedat, J., Gribnau, J., Barillot, E., Blüthgen, N., Dekker, J. and Gribnau, J. 2012. Spatial partitioning of the regulatory landscape of the $\mathrm{X}$ inactivation centre. Nature 485: 381-385.

Phimphan, S., Tanomtong, A., Supiwong, W., Nithikulworawong, N., Suvarnaraksha, A. and Kaewsri, S. 2015. Karyological analysis of the Barramundi, Lates calcarifer (Perciformes, Latidae). Cytologia 80: 167-172.

Rabl, C. 1885. Uber Zelltheilung. Wilhelm Engelmann, Leipzig.

Ruan, G.-P., Wang, J.-X., Yao, X., Pang, R.-Q., Cai, X.-M., He, J. and Pan, X.-H. 2013. Different hematopoietic reconstruction abilities of transplanted cells from bone marrow, spleen, liver and peripheral blood. Cytologia 78: 113-119.

Shavit, Y., Hamey, F. K. and Lio, P. 2014. FisHiCal: an R package for iterative FISH-based calibration of $\mathrm{Hi}-\mathrm{C}$ data. Bioinformatics 30: 3120-3122.

Shibata, F. and Hizume, M. 2015. Multi-color fluorescence in situ hybridization. Cytologia 80: 385-392.

Solovei, I., Cavallo, A., Schermelleh, L., Jaunin, F., Scasselati, C., Cmarko, D., Cremer, C., Fakan, S. and Cremer, T. 2002. Spatial preservation of nuclear chromatin architecture during threedimensional fluorescence in situ hybridization (3D-FISH). Exp. Cell Res. 276: 10-23.

Sultana, T., Sultana, S. S. and Alam, S. S. 2013. Karyotype and RAPD analysis to elucidate taxonomic status in two morphological forms of Egeria densa Planch. and Hydrilla verticillata (L.f.) Royle. Cytologia 78: 277-284.

Sumner, A. T. 2003. Chromosomes: Organization and Function. Blackwell Publishing, Oxford

Suto, Y., Akiyama, M., Gotoh, T. and Hirai, M. 2013. A modified protocol for accurate detection of cell fusion-mediated premature chromosome condensation in human peripheral blood lymphocytes. Cytologia 78: 97-103.

Suto, Y., Hirai, M., Akiyama, M., Suzuki, T. and Sugiura, N. 2012. Sensitive and rapid detection of centromeric alphoid DNA in human metaphase chromosomes by PNA fluorescence in situ hybridization and its application to biological radiation dosimetry. Cytologia 77: 261-267.

Suto, Y., Ishida, T. and Hirai, M. 2003. Multicolor karyotyping of six old world monkey species. Cytologia 68: 431-436. 
Tungkajiwangkoon, S., Inagaki, A., Shirakawa, J. and Hoshi, Y. 2015. RAPD profiling of three Japanese Drosera species. Cytologia 80: 393-398.

Williamson, I., Berlivet, S., Eskeland, R., Boyle, S., Illingworth, R. S., Paquette, D., Dostie, J. and Bickmore, W. A. 2014. Spatial genome organization: contrasting views from chromosome con- formation capture and fluorescence in situ hybridization. Genes Dev. 28: 2778-2791

Yokomi, I., Ogiwara, H., Kohno, T., Yokota, J. and Satoh, H. 2013. Comparative fiber-FISH reveals what happened at the integration site of the transfected plasmid DNA. Cytologia 78: 121-122. 